\title{
EVALUATION OF INNOVATIVE DIGITALLY CONTROLLED Er:YAG LASER IN SURGICAL TREATMENT OF ORAL LEUKOPLAKIA - A PRELIMINARY STUDY
}

\author{
Dragana Gabrić ${ }^{1}$, Vlaho Brailo ${ }^{2}$, Aleksandra Ivek ${ }^{3}$, Karla Krpan ${ }^{3}$, Nena Matulić ${ }^{4}$, \\ Danko Velimir Vrdoljak ${ }^{5}$, Anja Baraba ${ }^{6}$ and Vanja Vučićević Boras ${ }^{2}$
}

${ }^{1}$ Department of Oral Surgery, School of Dental Medicine, University of Zagreb, Zagreb, Croatia; ${ }^{2}$ Department of Oral Medicine, School of Dental Medicine, University of Zagreb,

Zagreb University Hospital Centre, Zagreb, Croatia;

${ }^{3}$ student, School of Dental Medicine, University of Zagreb, Zagreb, Croatia;

${ }^{4} \mathrm{PhD}$ student, School of Dental Medicine, University of Zagreb, Zagreb, Croatia;

${ }^{5}$ University Hospital for Tumors, Sestre milosrdnice University Hospital Centre, Zagreb, Croatia;

${ }^{6}$ Department of Endodontics and Restorative Dentistry, School of Dental Medicine, University of Zagreb, Zagreb, Croatia

\begin{abstract}
SUMMARY -The use of lasers for treatment of oral leukoplakia has gained a lot of interest in the past years, however, data on the use of Er:YAG laser are scarce. The aim of this study was to compare the efficacy of Er:YAG laser and 1\% topical isotretinoin in the treatment of 27 oral leukoplakia patients. Er:YAG laser (LightWalker AT, Fotona, Slovenia) was used in 27 patients with 27 leukoplakia lesions. Postoperative pain was assessed by use of visual analog scale (VAS), and the impact of laser treatment on the quality of life was assessed by the OHIP-14 questionnaire (Croatian version). Control group consisted of the same 27 patients previously treated with $1 \%$ topical isotretionin three times a day during the period of one year. No improvement in the size of leukoplakia lesions was observed after treatment with topical isotretinoin. There were significant differences between men and women according to leukoplakia localization, number of laser sessions and VAS $(p<0.05)$. At follow-up after six months and one year, there was no recurrence of lesions. Er:YAG laser is a successful treatment for oral leukoplakia. Topical isotretionin treatment is unsuccessful in patients with oral leukoplakia.
\end{abstract}

Key words: Leukoplakia, oral; Lasers, solid-state; Isotretinoin; Ablation techniques

\section{Introduction}

Leukoplakia is a clinical term used to describe a white plaque on the oral mucosa that cannot be removed by scraping and which has an unknown etiology except for cases of tobacco use $\mathrm{e}^{1,2}$. Various treatments have been suggested for the treatment of oral leukoplakia; however, the rate of its recurrence is still

Correspondence to: Assoc. Prof. Dragana Gabric, DMD, PhD, Department of Oral Surgery, School of Dental Medicine, University of Zagreb, Gundulićeva 5, HR-10000 Zagreb, Croatia

E-mail: dgabric@sfzg.hr

Received December 8, 2015, accepted January 5, 2017 high $^{3}$. Surgical treatment options for leukoplakic lesions may include scalpel excision, electrocoagulation, cryotherapy and laser therapy $\left(\mathrm{CO}_{2}, \mathrm{Er}, \mathrm{Cr}\right.$ :YSGG, Nd:YAG, KTP, Er:YAG). Pharmacological treatment possibilities include carotenoids, retinoids, topical antioxidants and bleomycin ${ }^{4}$. Lasers are widely used in medicine and dentistry owing to their beneficial effects such as coagulation properties (less perioperative and postoperative bleeding), and less edema and pain after surgical procedure. Furthermore, the use of ablative lasers results in good and fast healing process, a low level of patient discomfort during and after intervention, and rapid disappearance of postsurgical symp- 
toms. The main objective in the treatment of oral leukoplakia is to remove potentially neoplastic cells in an attempt to prevent malignant transformation ${ }^{5}$. In the searched literature on Pubmed (May, 2015), there are publications on the effectiveness of $\mathrm{CO}_{2}$ lasers in the treatment of oral leukoplakia. Nevertheless, to the best of our knowledge, there are only two reports on the use of Er:YAG lasers in the treatment of oral leukopla$\mathrm{kia}^{6,7}$. Er:YAG laser will ablate tissue efficiently at a relatively low fluence of about 0.5 to $1.5 \mathrm{~J} / \mathrm{cm}^{2}$ with minimal residual thermal damage ${ }^{8}$. Er:YAG laser is effective for superficial ablation, although deeper vaporization has been hampered by ineffective hemostasis ${ }^{8}$. Therefore, Er:YAG lasers are useful for lesions that are located in the superficial areas where a certain degree of hemostasis can be achieved. Using repetitive pulses at the same site can help in achieving significant degree of ablation while one pulse followed quickly by another will vaporize tissue before the area starts to bleed. Er:YAG laser is a very valuable tool in surgery as it has the coefficient degree of absorption by water ten times that of the $\mathrm{CO}_{2}$ laser ${ }^{9,10}$. Er:YAG laser minimally damages epithelial tissues, results in low inflammatory reaction, has quicker healing process and lower risk of scarring ${ }^{11}$. The latest laser technology allows for extremely precise ablation or excision of lesions using a digitally controlled dental laser handpiece ${ }^{12}$. This provides a possibility to guide the Er:YAG laser beam automatically in the required shape and dimension with precise coverage of relatively large areas ${ }^{13}$.

Various studies have evaluated therapeutic effectiveness of vitamin A derivatives in the treatment of oral leukoplakia, however, with inconsistent results. Most of the relatively scarce studies on topical use of isotretionin in various percentages report on improvement in patients with oral leukoplakia ${ }^{14-16}$.

Therefore, the aim of this preliminary study was to evaluate the effectiveness of ablative Er:YAG laser in comparison to the $1 \%$ topical isotretionin therapy in the treatment of oral leukoplakia. Another aim of the study was to evaluate the quality of life and postoperative pain after laser treatment.

\section{Subjects and Methods}

The study was approved by the Ethics Committee, School of Dental Medicine, University of Zagreb. Every participant signed informed consent according to
Helsinki II. The study was performed at the Department of Oral Medicine and Department of Oral Surgery, School of Dental Medicine in Zagreb, Croatia. There were 27 patients ( 17 women and $10 \mathrm{men}$ ), age range 24-73 years, with 27 leukoplakic lesions involved in this study. Detailed medical history was taken and clinical examination performed in all patients. All 27 leukoplakic lesions were histopathologically confirmed as oral leukoplakia prior to any treatment. Lesions were measured (in millimeters), exact localization of the leukoplakic lesions was recorded, as well as data regarding tobacco and alcohol consumption. As the first option, in every participant leukoplakia was treated with $1 \%$ topical isotretinoin in orabase (Roaccu$\operatorname{tane}^{\circledR}$, Hoffmann-La Roche, Basel, Switzerland), and Orabase $^{\circledR}$ (ConvaTec, Deeside, United Kingdom), mixed in the same amounts, which was applied three times a day during the period of one year. Then the lesions were re-measured and there were no differences in the lesion size, except for one patient in whom the lesion was smaller but still present. Then, an Er:YAG laser (LightWalker AT, Fotona, Slovenia) with a noncontact X-Runner digitally controlled hand piece was used on the same group of participants. This digitally controlled hand piece for Er:YAG laser, with integrated scanning mechanism within the ergonomic box lies on the operator's hand. The treatment area and size was defined on the device by the operator according to the shape and size of treated lesion, and the laser beam was automatically guided across the treated tissue surface. There were three primary treatment shapes (circular, rectangular and hexagonal) that could be selected with the X-Runner hand piece, and these could be set according to the size of treatment area (width and length of the rectangle, or diameter in case of circle and hexagon), up to $6 \mathrm{~mm}$. After applying local anesthetic (Ubistesin 2\%, 3M ESPE, Seefeld, Germany), up to $1 \mathrm{~mL}$, depending on the size and localization of the lesion, laser parameters were selected. Er:YAG laser was used in a non-contact mode and settings were as follows: pulse mode was Quantum Square Pulse (QSP), pulse energy of $120 \mathrm{~mJ}$ and frequency of 20 $\mathrm{Hz}$. Round, rectangular or hexagonal shape was selected according to the size and shape of the lesion. The hand piece was held at a distance of $15 \mathrm{~mm}$ from the lesion surface and water spray level was set to 10 $\mathrm{mL} / \mathrm{min}$. All hyperkeratotic lesions were removed completely by the laser ablation process and the num- 
Table 1. Demographic and clinical data on oral leukoplakia patients

\begin{tabular}{|c|c|c|c|}
\hline \multirow{2}{*}{$\begin{array}{l}\text { Gender, n (\%): } \\
\text { Male } \\
\text { Female }\end{array}$} & \multirow[b]{2}{*}{$\begin{array}{l}10(37) \\
17(63) \\
\end{array}$} & Gender difference & Recurrence difference \\
\hline & & & 0.148 \\
\hline Age (yrs, mean \pm SD) & $53 \pm 13$ & 0.459 & 0.643 \\
\hline \multirow{3}{*}{$\begin{array}{l}\text { Smoking: } \\
\text { Yes } \\
\text { No } \\
\text { Cigarettes/day (mean } \pm \mathrm{SD})\end{array}$} & \multirow{3}{*}{\begin{tabular}{|l}
$9(33.3)$ \\
$18(66.7)$ \\
$18 \pm 10$
\end{tabular}} & & \\
\hline & & 0.260 & 0.121 \\
\hline & & 0.809 & 0.471 \\
\hline Lesion $\left(\mathrm{mm}^{2}\right.$, mean $\left.\pm \mathrm{SD}\right)$ & $74 \pm 90$ & 0.166 & 0.381 \\
\hline \multicolumn{4}{|l|}{ Localization: } \\
\hline $\begin{array}{l}\text { Buccal mucosa } \\
\text { Tongue } \\
\text { Sublingual mucosa } \\
\text { Other }\end{array}$ & $\begin{array}{l}11(40.7) \\
6(22.2) \\
3(11.1) \\
7(26)\end{array}$ & $<0.001^{*}$ & $0.004^{*}$ \\
\hline \multirow{2}{*}{$\begin{array}{l}\text { Localization side, n (\%): } \\
\text { Left } \\
\text { Right }\end{array}$} & \multirow[b]{2}{*}{$\begin{array}{l}11(40.7) \\
16(59.3)\end{array}$} & & \\
\hline & & 0.453 & 0.895 \\
\hline
\end{tabular}

*statistically significant $(\mathrm{p}<0.05)$

ber of ablations depended on lesion size. Patients were recalled and examined after one, two, four, eight weeks, six months and one year after the first ablation. At the follow-up, every lesion was re-measured if needed or still present and decided whether there was a need to repeat laser treatment. The lesions where relapse was observed were ablated once more to final removal. Postoperative pain was determined by the visual analog scale (VAS), range $0-10$, where 0 denotes no pain and 10 worst pain. Furthermore, each patient filled in the Oral Health Impact Profile (OHIP), which consisted of 14 questions on the impact of laser treatment on the quality of their life. The normality of distribution was tested with Kolmogorov-Smirnov test. Since data were normally distributed, $\chi^{2}$-test and Pearson's correlation were used on further analysis. Differences between male and female subjects and differences based on recurrence rate were calculated by $\chi^{2}$-test for categorical variables and Student's t-test for continuous variables. The level of statistical significance was set at $\mathrm{p}<0.05$. The study was initiated in June 2013 and completed in November 2014.

\section{Results}

There were no differences in the size of leukoplakic lesions before and after topical isotretinoin treatment, except for one patient. There were significant differences between men and women in laser group according to localization of leukoplakic lesions, number of laser sessions and VAS ( $\mathrm{p}<0.05)$ (Tables 1 and 2). All leukoplakic lesions found sublingually were observed in women. Men had more laser sessions when compared to women $(p=0.036)$. Women tended to have higher VAS scores in comparison to men $(\mathrm{p}=0.008)$. Recurrence rate of leukoplakic lesions was $74.1 \%$ after first ablation treatment (Table 2). Follow-up of the lesions was performed after one, two, four, eight weeks, six months and one year. Some of the patients had few ablations per visit. However, at the recall visits after six months and one year, there was no recurrence of leukoplakic lesions ablated using Er:YAG laser. The OHIP total score was 9.6 \pm 9.8 , without any statistically significant differences between men and women in this group $(p>0.05)$ (Table 2).

\section{Discussion}

There are scarce data on the effectiveness of Er:YAG lasers in the treatment of oral leukoplakia ${ }^{6,7}$. Meister et al. ${ }^{6}$ report a case of Er:YAG use for the treatment of leukoplakia of buccal mucosa. Schwarz et al. ${ }^{7}$ treated ten patients with 16 leukoplakic lesions with Er:YAG or $\mathrm{CO}_{2}$ lasers. The aim of this preliminary study was to 
Table 2. Data on laser parameters, number of ablations, recurrence rate, VAS and OHIP

\begin{tabular}{|c|c|c|c|}
\hline \multirow{2}{*}{$\begin{array}{l}\text { Laser parameter - shape, } \mathrm{n}(\%) \text { : } \\
\text { Circle } \\
\text { Rectangle } \\
\text { Combination }\end{array}$} & \multirow[b]{2}{*}{$\begin{array}{l}10(37) \\
8(29.6) \\
9(33.3)\end{array}$} & Gender difference & Recurrence difference \\
\hline & & 0.456 & 0.926 \\
\hline \multirow{2}{*}{\begin{tabular}{|l}
$\begin{array}{l}\text { Number of ablations per visit, } \mathrm{n}(\%): \\
\leq 10 \\
11-20 \\
>20\end{array}$ \\
\end{tabular}} & \multirow[b]{2}{*}{$\begin{array}{l}7(25.9) \\
16(59.3) \\
4(14.8)\end{array}$} & & \\
\hline & & 0.05 & 0.694 \\
\hline Number of laser sessions (mean $\pm \mathrm{SD}$ ) & $2 \pm 0.8$ & $0.036^{*}$ & $<0.001^{*}$ \\
\hline \multirow{2}{*}{$\begin{array}{l}\text { Recurrence: } \\
\text { Yes } \\
\text { No }\end{array}$} & \multirow[b]{2}{*}{$\begin{array}{l}20(74.1) \\
7(25.9)\end{array}$} & & \\
\hline & & 0.148 & \\
\hline VAS $($ mean $\pm \mathrm{SD})$ & $2 \pm 3$ & $0.008^{*}$ & 0.200 \\
\hline OHIP & $9 \pm 9$ & 0.493 & 0.283 \\
\hline
\end{tabular}

VAS = visual analog scale; OHIP = Oral Health Impact Profile; ${ }^{*}$ statistically significant $(\mathrm{p}<0.05)$

evaluate the effectiveness of Er:YAG laser with a noncontact X-Runner digitally controlled hand piece in the treatment of oral leukoplakia. The great advantage of such a hand piece is the ability to treat relatively large areas of different shapes extremely precisely and uniformly. The laser beam in this case is automatically guided, which allows the use of higher repetitions and faster finishing of the procedure. Furthermore, the QSP mode was used in the present study. QSP is a specific pulse mode in which a longer laser pulse is divided (quantized) into several super-short pulses that follow each other at an optimally fast rate ${ }^{17}$. This enables the QSP mode to deliver super-short, low-energy pulses with efficiency of long-duration, higher energy laser pulses without sacrificing the efficiency and precision that is provided by super-short duration pulses ${ }^{17}$. Regarding removal of soft tissues, the ablation is very precise and heals even faster than with longer pulse mode due to the minimally invasive delivery of short, low energy pulses of high frequency ${ }^{12}$.

Since there were no differences in the size of leukoplakic lesions before and after topical isotretinoin treatment, except for one patient, only results recorded in the laser group were analyzed. The results of this study showed gender differences according to localization of leukoplakic lesions, number of laser sessions and VAS score in the laser group of patients. All sublingual lesions were observed in women. Study results revealed that sublingual leukoplakia recurred less frequently as compared to leukoplakia on buccal mucosa and tongue. It seems that sublingual area is the one without recurrences probably owing to higher vascularization of the area in comparison to other treated areas. Furthermore, it may be that tongue protects sublingual area from mechanical injuries. The last but not the least, saliva secreted from the submandibular and sublingual glands has a protective role, especially as it contains mucins, unlike parotid saliva. Significantly more laser sessions recorded in men probably reflect the finding that men tended to have lesions on buccal mucosa, unlike women who tended to have lesions sublingually. It might be that buccal mucosa is more prone to mechanical trauma due to mastication and therefore recurrences in this area are more frequent. Contrary to our results, Jerjes et al. ${ }^{18}$ report that recurrence of leukoplakia does not correlate with its localization.

According to the results of this study, the recurrence rate of leukoplakic lesions was $74.1 \%$ in general. However, at the recall visits after six months and one year, there was no recurrence of any leukoplakic lesion. In the present study, when the lesions were removed with laser for the first time, ablation of the epithelial tissue was performed with little or no capillary bleeding from the connective tissue. On a subsequent visit, if recurrence of the lesion was observed, ablation was performed to a greater depth with capillary bleeding and there was no recurrence at the recall after six months and one year. It is important to ascertain the borders of the lesion, including its margin and depth. 
If the ablation depth is not sufficient, the remaining basal cell layer may consist of highly proliferating cells, which may cause recurrence of leukoplakia ${ }^{17}$. Probably these proliferating cells, which remained after the first laser ablation in this study, caused recurrence of leukoplakia and were removed in the next session when deeper ablation was performed to ensure complete removal of the lesion. Other studies report different data regarding recurrence of leukoplakia. The results reported by Schwartz et al. ${ }^{7}$ revealed that Er:YAG laser exhibited complete elimination of three leukoplakic lesions and partial elimination of five lesions within the testing period. Thomson and $\mathrm{Wylie}^{3}$ report on the $24 \%$ recurrence rate after laser surgery, similar to the results reported by Ishii et al. ${ }^{17}$, who found recurrence of leukoplakia in $29 \%$ of cases. Brouns et al. ${ }^{19}$ report on $8 \%$ and Jerjes et al. ${ }^{18}$ on $19.5 \%$ rate of leukoplakia recurrence after laser ablation. The results of our study are in concordance with the results of Meister et al. ${ }^{6}$, which showed complete disappearance of oral leukoplakia by use of Er:YAG laser.

Differences between the results of this study and those from other studies found in the literature could be due to different laser devices, hand pieces and parameters chosen, as well as to differences in the methodology employed in particular studies.

Scardina et al. ${ }^{14}$ compared the efficacy of $0.18 \%$ topical isotretinoin with $0.05 \%$ topical isotretinoin for the treatment of oral leukoplakia in 40 patients. The drug was applied twice a day for three consecutive months and there was significant reduction in lesions (85\%), with no documented topical or systemic adverse reactions at $0.18 \%$ concentration. Tetè et al. ${ }^{15}$ evaluated the role of bcl-2 protein and apoptotic bodies in topical treatment of oral leukoplakia with $0.1 \%$ isotretinoin gel (applied three times a day) in $15 \mathrm{pa}^{-}$ tients. In 14 patients, there was marked improvement of the dimension and clinical aspect of the lesions (total remission in three and improvement of the size and clinical appearance of the lesion by $50 \%$ or more in 11 cases). Piattelli et al. ${ }^{16}$ treated ten patients with oral leukoplakia with $0.1 \%$ isotretinoin gel (three topical applications) and the lesions subsided completely in two patients, whereas $50 \%$ improvement was recorded in eight patients. However, the results of our study showed that there was no improvement in the size of leukoplakic lesions treated with topical isotretionin even in higher concentration during the one-year pe- riod. Therefore, we do not suggest topical treatment in patients with oral leukoplakia.

Although Er:YAG laser revealed successful results in the treatment of oral leukoplakia, patients have to be advised that close follow-up (every six months) is advisable as there is the risk of recurrence of the previously ablated lesions, as well as development of new lesions over time.

\section{Conclusion}

We conclude that the Er:YAG laser with a noncontact X-Runner digitally controlled hand piece may be a successful treatment option for leukoplakia as no recurrence of lesions was observed at one-year followup. On the contrary, 1\% topical isotretinoin treatment was unsuccessful in the same group of patients.

\section{References}

1. Warnakulasuriya S, Johnson NW, van der Waal I. Nomenclature and classification of potentially malignant disorders of the oral mucosa. J Oral Pathol Med. 2007;36(10):575-80. doi: 10.1111/j.1600-0714.2007.00582.x

2. Rotim Z, Bolanca Z, Rogulj AA, Andabak M, Vucicevic Boras V, Vrdoljak DV. Oral lichen planus and oral lichenoid reaction - an update. Acta Clin Croat. 2015;54(4):516-20.

3. Thomson PJ, Wylie J. Interventional laser surgery: an effective surgical and diagnostic tool in oral precancer management. Int J Oral Maxillofac Surg. 2002;31(2):145-53. doi: 10.1054. ijom.2001.0189

4. Van der Waal I. Potentially malignant disorders of the oral and oropharyngeal mucosa: present concepts of management. Oral Oncol. 2010;46(6):423-5. doi:10.1016/j.oraloncology. 2010.02.016.

5. Lodi G, Porter S. Management of potentially malignant disorders: evidence and critique. J Oral Pathol Med. 2008;37(2): 63-9. doi: 10.1111/j.1600-0714.2007.00575.x

6. Meister J, Franzen R, Eyrich G, Bongartz, J, Gutknecht N, Hering $\mathrm{P}$. First clinical application of a liquid-core light guide connected to an Er:YAG laser for oral treatment of leukoplakia. Laser Surg Med. 2010;25(5):669-73. doi: 10.1007/s10103010-0782-0.

7. Schwartz F, Maraki D, Yalcinkaya S, Bieling K, Böcking A, Becker J. Cytologic and DNA-cytometric follow-up of oral leukoplakia after CO2- and Er:YAG laser assisted ablation: a pilot study. Laser Surg Med. 2005;37(1):29-36. doi: 10.1002. 1sm.20188

8. Zachary CB. Modulating the Er:YAG laser. Laser Surg Med. 2000;26(2):223-6. doi: 10.1002/(sici)1096-9101(2000)26:2< 223::aid-1sm14>3.0.co;2-k 
9. Hale GM, Querry MR. Optical constants of water in the 200 $\mathrm{nm}$ to 200 micron wavelength region. Appl Optics. 1973; 12(3):555-63. doi: 10.1364/AO.12.000555.

10. Robertson CW, Williams D. Lambert absorption coefficients of water in the infrared. J Opt Soc Am. 1971;61(10):1316-20.

11. McDaniel DH, Lord J, Ash K, Newman J. Combined CO2/ Erbium:YAG laser resurfacing of peri-oral rhytides and side-byside comparison with carbon dioxide laser alone. Dermatol Surg. 1999;25(4):285-93. doi: 10.1046/j.1524-4725.1999.08162.x

12. Gabrić Pandurić D, Katanec D, Filipović Zore I. Clinical cases of soft tissue surgery with X-runner in QSP mode. J LAHA. 2013;2(2):34-7.

13. Lukac M, Malej Primc N, Pirnat S. Quantum square pulse Er:YAG lasers for fast and precise hard dental tissue preparation. J LAHA. 2012;1(2):14-21.

14. Scardina GA, Carini F, Maresi E, Valenza V, Messina P. Evaluation of the clinical and histological effectiveness of isotretinoin in the therapy of oral leukoplakia: ten years of experience: is management still up to date and effective? Methods Find Exp Clin Pharmacol. 2006;28(2):115-9. doi: 10.1358/ mf.2006.28.2.977843
15. Tetè S, Pappalardo S, Rubini C, Salini L, Falco A, Perfetti EG. The role of apoptosis and bcl-2 protein in topical treatment of oral leukoplakia with isotretinoin. Minerva Stomatol. 1999; 48(9):411-8.

16. Piattelli A, Fioroni M, Santinelli A, Rubini C. Bcl-2 expression and apoptotic bodies in 13-cis-retinoic acid (isotretinoin)-topically treated oral leukoplakia: a pilot study. Oral Oncol. 1999;35(3):314-20. doi: 10.1016/s1368-8375(98)00095-5

17. Ishii J, Fujita K, Komori T. Laser surgery as a treatment for oral leukoplakia. Oral Oncol. 2003;39(8):759-69. doi: 10.1016/ s1368-8375(03)00043-5

18. Jerjes W, Upile T, Hamdoon Z, Al-Khawalde M, Morcos M, Mosse CA, Hopper C. CO2 laser of oral dysplasia: clinicopathological features of recurrence and malignant transformation. Lasers Med Sci. 2012;27(1):169-79. doi: 10.1007/ s10103-011-0916-z.

19. Brouns E, Baart J, Karagozoglu K, Aartman I, Bloemena E, van der Waal I. Treatment results of CO2 laser vaporisation in a cohort of 35 patients with oral leukoplakia. Oral Dis. 2014; 20(3):e19-24. doi: 10.1111/odi.12007.

Sažetak

\title{
EVALUACIJA INOVATIVNO DIGITALNO KONTROLIRANOG Er:YAG LASERA U LIJEČENJU LEUKOPLAKIJE - PROBNO ISTRAŽIVANJE
}

\author{
D. Gabrić, V. Brailo, A. Ivek, K. Krpan, N. Matulić, D.V. Vrdoljak, A. Baraba i V. Vučicević Boras
}

Posljednjih godina postoji veliko zanimanje za upotrebu lasera u liječenju oralne leukoplakije, ali su podatci o upotrebi Er:YAG lasera malobrojni. Cilj ovoga istraživanja bio je usporediti učinak Er:YAG lasera i 1\%-tnog topikalnog izotretinoina u liječenju 27 bolesnika s oralnom leukoplakijom. Er:YAG laser (LightWalker AT, Fotona, Slovenia) je korišten u 27 bolesnika s 27 leukoplakičnih lezija. Poslijeoperacijska bol je određena uz pomoć vizualne analogne ljestvice (visual analog scale, VAS), a utjecaj na kvalitetu života mjeren je pomoću upitnika OHIP-14 (hrvatska verzija). Kontrolna skupina se sastojala od istih 27 bolesnika koji su prije toga liječeni 1\%-tnim topikalnim izotretioninom tri puta na dan tijekom tri mjeseca. Nije bilo poboljšanja u veličini lezija leukoplakije nakon topikalno primijenjenog izotretinoina. Utvrđene su značajne razlike između muškaraca i žena s obzirom na lokalizaciju leukoplakije, broj laserskih zahvata i rezultata VAS ( $<<0,05)$. Šest mjeseci i godinu dana od laserskog zahvata nije bilo recidiva oralne leukoplakije. Er:YAG laser je uspješna terapija u liječenju oralne leukoplakije. Topikalna primjena izotretionina nije uspješna u liječenju oralne leukoplakije.

Ključne riječi: Leukoplakija, oralna; Laseri, kruti; Izotretinoin; Ablacija, tehnike 